\title{
C-C Chemokine Receptor Type 2
}

National Cancer Institute

\section{Source}

National Cancer Institute. C-C Chemokine Receptor Type 2. NCI Thesaurus. Code C101579.

C-C chemokine receptor type 2 ( $374 \mathrm{aa}, \sim 42 \mathrm{kDa}$ ) is encoded by the human CCR2 gene. This protein plays a role in both cytokine binding and receptor signaling. 